\title{
P07 - Treatment load in the therapy management of allergic rhinitis: a UK retrospective database study
}

\author{
Victoria Carter ${ }^{1 *}$, David Price ${ }^{2}$, Glenis Scadding ${ }^{3}$, Shuaib Nasser ${ }^{4}$, Claus Bachert ${ }^{5}$, Hesham Saleh ${ }^{6}$, Julian Maitland ${ }^{7}$, \\ Julie von Ziegenweidt ${ }^{8}$, Dermot Ryan ${ }^{9}$
}

From 3rd Pediatric Allergy and Asthma Meeting (PAAM)

Athens, Greece. 17-19 October 2013

\section{Background}

Allergic rhinitis (AR) is poorly controlled. Treated patients, even those on multiple therapies still experience symptoms. In a UK survey, $70.5 \%$ of moderate-to-severe AR patients took $\geq 2$ medications (either $\mathrm{Rx}$ or over the counter) in an attempt to achieve better and faster symptom relief.

\section{Aim}

To explore the extent of co-prescribing by UK general practitioners (GPs) during the hay-fever season in patients with seasonal AR (SAR), perennial AR (PAR), and comorbid asthma.

\section{Method}

A retrospective database study using the Optimum Patient Care Research Database consisting of data extracted from
GP records supplemented with patient-reported outcomes from questionnaires. Patients included in the analysis had a recorded AR diagnosis and $\geq 1$ AR therapy scripts during 1st March 2010 to 31st August 2010.

\section{Results}

In all, 22,381 AR patients were included. Results are summarized in the table.

\section{Conclusion}

In contrast to previous surveys, these data relate to prescriptions only and show a high level of co-prescribing behavior among UK GPs. There was a significant shift to combination therapy during the season, particularly for PAR patients, with strong co-prescription evident regardless of asthma co-morbidity. These data indicate that

Table 1

\begin{tabular}{|c|c|c|c|c|}
\hline \multicolumn{5}{|c|}{ 1st March 2010 to 31st August 2010} \\
\hline \multirow[b]{2}{*}{ Therapy, n (\%) } & \multicolumn{2}{|l|}{ SAR $(n=16187)$} & \multicolumn{2}{|l|}{ PAR $(n=6194)$} \\
\hline & Season Start & Season End & Season Start & Season End \\
\hline Single therapy & $10776(65.5)$ & $8850(54.7)$ & $4764(76.9)$ & $2974(48.0)$ \\
\hline Dual therapy & $3782(23.4)$ & $5213(32.2)$ & $1172(18.9)$ & $2445(39.5)$ \\
\hline Triple therapy & $1615(10.0)$ & $2062(12.7)$ & $244(3.9)$ & $694(11.2)$ \\
\hline Quadruple therapy & $24(0.1)$ & $62(0.4)$ & $14(0.2)$ & $77(1.2)$ \\
\hline 5 therapies & $0(0.0)$ & $0(0.0)$ & $0(0.0)$ & $4(0.1)$ \\
\hline Total on combinations & $5421(33.5)$ & $7337(45.3)$ & $1430(23.0)$ & $3220(52.0)$ \\
\hline \multirow[t]{2}{*}{ Season End, n (\%) } & \multicolumn{2}{|c|}{ Asthma $(n=8787)$} & \multicolumn{2}{|c|}{ Non Asthma $(n=13594)$} \\
\hline & SAR & PAR & SAR & PAR \\
\hline \multicolumn{5}{|l|}{ Combination therapy } \\
\hline $\begin{array}{l}\text { Start of season } \\
\text { End of season }\end{array}$ & $\begin{array}{l}1536(24.6) \\
2296(41.6)\end{array}$ & $\begin{array}{l}780(23.9) \\
1805(55.2)\end{array}$ & $\begin{array}{l}3885(36.4) \\
5041(47.2)\end{array}$ & $\begin{array}{l}650(22.2) \\
1415(48.4)\end{array}$ \\
\hline
\end{tabular}

${ }^{1}$ Research in Real Life, Cambridge, United Kingdom

Full list of author information is available at the end of the article 
(i) UK GPs are aware that current therapy provides insufficient symptom relief, (ii) that AR is a costly disease to treat requiring several GP visits over the season for therapy modification and (iii) there is a need for an AR therapy which provides more complete symptom relief.

\section{Authors' details}

${ }^{1}$ Research in Real Life, Cambridge, United Kingdom. ${ }^{2}$ University of Aberdeen, Aberdeen, United Kingdom. ${ }^{3}$ RNTNE Hospital, London, United Kingdom. ${ }^{4}$ Cambridge University Hospitals NHS Foundation Trust, Cambridge, United Kingdom. ${ }^{5}$ University Hospital Ghent, Ghent, Belgium. ${ }^{6}$ Imperial College of Medicine, London, United Kingdom. ${ }^{7}$ Meda Pharmaceuticals, London, United Kingdom. ${ }^{8}$ Research in Real Life, Norwich, United Kingdom. ${ }^{9}$ East Midlands Strategic Health Authority, Leicester, United Kingdom.

Published: 28 February 2014

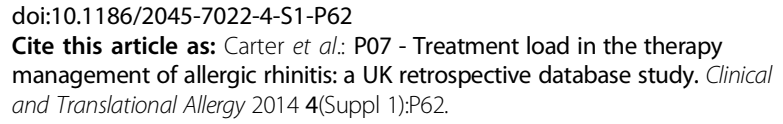

Submit your next manuscript to BioMed Central and take full advantage of:

- Convenient online submission

- Thorough peer review

- No space constraints or color figure charges

- Immediate publication on acceptance

- Inclusion in PubMed, CAS, Scopus and Google Scholar

- Research which is freely available for redistribution 